\title{
O PROCESSO DE IMPEACHMENT NO BRASIL E O ESTADO DEMOCRÁTICO DE DIREITO
}

\author{
Manoel Messias Peixinho ${ }^{1}$
}

\section{Resumo}

O processo de impeachment do Presidente da República é um processo jurídico e político regulado pela Constituição, regulamentado pela Lei no 1.079/1950 e pelos Regimentos Internos da Câmara dos Deputados e do Senado Federal. O Supremo Tribunal Federal-STF também regulamentou (ADPF $378 \mathrm{MC} / \mathrm{DF}$ ) o processo de impeachment e deu nova interpretação aos dispositivos da Lei no 1.079/1950 e dos Regimentos Internos da Câmara dos Deputados e do Senado Federal. Porém, o STF entendeu que não era de sua competência manifestar-se sobre o mérito do processo de impeachment por ser uma competência exclusiva do Parlamento, o que significou um consentimento velado a um golpe parlamentar perpetrado pelas forças conservadoras das elites brasileiras e pela grande mídia. A deposição da Presidenta da República por meio do processo de impeachment foi uma fraude jurídica e um golpe parlamentar oportunista.

Palavras-chaves: Processo de Impeachment; Processo Jurídico e Político; Constituição Federal; Lei n ${ }^{\circ}$ 1.079/1950; Supremo Tribunal Federal; Mérito do Processo de Impeachment; Fraude Jurídica; Golpe Parlamentar.

\section{INTRODUÇÃO}

O objetivo deste trabalho é estudar o instituto do impeachment a partir dos fundamentos do direito administrativo e do direito constitucional vinculados aos princípios fundamentais do Estado Democrático de Direito. É de conhecimento público que o Brasil está passando por uma grave crise econômica e política e que houve um embate ideológico entre os partidos de situação e oposição sobre os fundamentos jurídicos que ensejaram o impedimento da Presidenta da República. Como bem acentua Maurice Duverger (1996, p. 582), a ausência de consenso majoritário faz com que a composição do Parlamento interdite a formação de uma maioria parlamentar disciplinada e relativamente coerente, suscetível de perdurar normalmente durante uma legislatura. Assim, na ausência de maioria parlamentar estável e homogênea, os Parlamentos são onipotentes na aparência e os governos são frágeis. Neste artigo não será feito um estudo da conjuntura política na qual se insere o 
procedimento de impedimento da Chefe do Poder Executivo Federal. Antes, far-se-á uma análise fundada na Constituição Federal, na Lei no 1.079/1950 e nos Regimentos Internos da Câmara dos Deputados e do Senado Federal, acrescido de um detalhamento contextualizado da jurisprudência do Supremo Tribunal Federal.

Há estudos e pareceres sobre o processo de impedimento que já foram elaborados por estudiosos a partir de contributos do direito financeiro e tributário, o que não foi obstáculo para que fossem feitas nesse artigo referências pontuais sobre os referidos estudos especializados.

Há um problema central que deve ser enfrentado neste trabalho. $\mathrm{O}$ processo de impedimento do Presidente da República é regulado pela Constituição brasileira, regulamentado pela Lei no 1.079/1950 e pelos Regimentos Internos da Câmara dos Deputados e do Senado Federal, mas os julgadores são Deputados Federais e Senadores que não estão vinculados a qualquer motivação jurídica. Os parlamentares decidem, exclusivamente, segundo suas convicções políticas e subjetivas e são movidos, não raramente, por interesses não republicanos. Dessa forma, ainda que todo o processo de impeachment seja regulado por normas jurídicas, a decisão final de condenar ou absolver o acusado se dá no campo político e patrimonialista em que os interesses pessoais e partidários predominam sobre a rigidez jurídica.

Há três hipóteses que podem ser respondidas provisoriamente. A primeira hipótese é que processo de impedimento é regulado pelo ordenamento jurídico brasileiro, sem prejuízo de haver dois tribunais políticos que dão a palavra final sobre o processo de impeachment, quais sejam: a Câmara dos Deputados e o Senado Federal, compostos por juízes políticos (Deputados Federais e Senadores). A segunda hipótese é que o Supremo Tribunal Federal tem competência para controlar tanto as regras formais quanto os tipos materiais presentes no processo de impeachment. Ou seja, o mérito do processo de impeachment deve ser controlado pelo STF quando houver violação à Lei no 1.079/1950, às normas constitucionais que regulam a matéria e aos Regimentos Internos da Câmara dos Deputados e do Senado Federal. A terceira hipótese, inter-relacionada à segunda, assenta-se na premissa de que não há discricionariedade dos Deputados Federais e Senadores na aplicação das normas constitucionais e infraconstitucionais que regulam o impeachment porque as tipificações que configuram os crimes de responsabilidade estão previstas em atos normativos e são passíveis de controle pelo STF.

A metodologia utilizada será baseada nos princípios norteadores do direito Constitucional e do direito administrativo, com remissões ao direito financeiro e ao direito processual penal.

As fontes pesquisadas são exclusivamente bibliográficas com uma abordagem que privilegia o direito administrativo, o direito constitucional e a jurisprudência do Supremo Tribunal Federal.

\footnotetext{
${ }^{1}$ Professor (Ph.D.) de Direito Administrativo na Pontifícia Universidade Católica do Rio de Janeiro (PUC-RIO). Professor de Direito Constitucional da Universidade Cândido Mendes. E-mail: peixinho@mcp-advogados.com.br
} 
O Estado Democrático de Direito, segundo José Afonso da Silva (2000, p.14), é “a realização dos valores da igualdade, liberdade e dignidade da pessoa. São valores que alicerçam a convivência humana”. Este conceito abrange o Estado de Direito, de viés liberal. Com as transformações históricas e a superação do liberalismo clássico, o Estado Democrático de Direito se vinculou à democracia, fonte de legitimidade de todos os poderes estatais e dos direitos fundamentais. A democracia, associada ao Estado de Direito, há que assegurar a igualdade substancial para que sejam estabelecidas regras que reconheçam as diferenças sociais, culturais e econômicas indispensáveis à convivência social (PEIXINHO, 2010, p.130).

\section{CONCEITO DE IMPEACHMENT}

A expressão impeachment é derivada do francês (empêcher) e significa literalmente impedir, dificultar, acusar, imputar algum ilícito ou defeito a alguém. Impeachment significa, ainda, desacreditar a retidão, conduta e a credibilidade (BABCOCK GOVE, 1961, p. 765). O sentido de impeachment também é utilizado para denotar um processo instaurado contra um agente público, instituído por uma acusação escrita. Na Inglaterra é privilégio da Câmara dos Comuns a instauração do impeachment, mas fica a cargo da Câmara dos Lordes julgá-lo no mérito. Nos Estados Unidos, o início do processo de impedimento começa na Câmara dos Deputados e o julgamento da responsabilidade cabe ao Senado (BLACK, M. A, 1990, p. 989 e LEAL, 1925, p. 436). No Brasil, similar aos países referenciados, o processo de impedimento tem início com a autorização da Câmara dos Deputados e o julgamento fica a cargo do Senado Federal.

\section{O RITO DO PROCESSO DE IMPEACHMENT}

O rito processual adotado no caso de impedimento do Presidente da República está previsto na Constituição, regulado pela Lei no 1.079/1950 e pelos Regimentos Internos da Câmara dos Deputados e do Senado Federal. Porém, a jurisprudência do STF (ADPF 378 MC / DF²) alterou o teor de diversos dispositivos da Lei no 1.079/1950 e dos Regimentos Internos.

\section{A INSTAURAÇÃO DO PROCESSO DE IMPEACHMENT NA CÂMARA DOS DEPUTADOS}

${ }^{2}$ ADPF 378 MC/DF-DISTRITO FEDERAL. MEDIDA CAUTELAR NA ARGUIÇÃO DE DESCUMPRIMENTO DE PRECEITO FUNDAMENTAL Relator (a): Min. EDSON FACHIN. Relator (a) p/ Acórdão: Min. ROBERTO BARROSO Julgamento: 17/12/2015. Órgão Julgador: Tribunal Pleno. Publicação. PROCESSO ELETRÔNICO. DJe-043 DIVULG 07-032016. Publicado em 08-03-2016. 
O processo de impeachment se inicia com uma denúncia à Câmara dos Deputados que pode ser feita por qualquer cidadão que tenha conhecimento de fatos que se configurem crime de reponsabilidade ${ }^{3}$. A denúncia deve ser fundamentada com a exposição de fatos e fundamentos legais que demonstrem que a condutada do acusado se enquadra nos casos previstos na Constituição, na Lei no 1.079/1950 e nos Regimentos Internos da Câmara dos Deputados e do Senado Federal.

\section{A DENÚNCIA NO PROCESSO DE IMPEACHMENT}

Compete ao Presidente da Câmara dos Deputados fazer o exame preliminar de admissibilidade da denúncia. A avaliação dos pressupostos para o exame da denúncia não se funda em decisão discricionária. Seria absurda a adoção da discricionariedade no exame da denúncia porque os crimes de responsabilidades estão exaustivamente previstos nos atos normativos reguladores do impeachment.

Da decisão que defere ou indefere o processamento da denúncia, cabe controle jurisdicional pelo Supremo Tribunal Federal porque a suposta conduta ilícita imputada ao agente político tem tipificação discriminada. Se a denúncia for deferida, desde que preenchidos os requisitos normativos, será encaminhada a peça de libelo a uma Comissão Especial que a processará.

\section{A ADMISSIBILIDADE DO IMPEACHMENT NA COMISSÃO ESPECIAL}

Uma vez deferida a denúncia pelo Presidente da Câmara, inicia-se o processo de admissibilidade do impedimento do Presidente da República na Comissão Especial, que se reunirá no prazo de 48 (quarenta e oito horas) para eleger o Presidente e Relator. ${ }^{4} \mathrm{O}$ acusado deve ser citado para apresentar a sua defesa prévia de dez sessões ${ }^{5}$ e a previsão para o término dos trabalhos da Comissão será de dez dias com a elaboração de parecer conclusivo sobre a admissibilidade da denúncia. ${ }^{6}$ A defesa deve demonstrar que a denúncia não está devidamente fundamentada com os argumentos jurídicos e com as provas que comprovam a prática indiciária do crime de responsabilidade. ${ }^{7}$ Porém, nesta fase processual, não há uma defesa de mérito com um lastro probatório rigoroso ${ }^{8}$.

A defesa deve demonstrar apenas a atipicidade da conduta supostamente ilícita. $\mathrm{Na}$ defesa prévia não devem ser desprezadas as provas que possam desconstituir uma denúncia inepta ou infundada. ${ }^{9}$ Se a peça de

\footnotetext{
${ }^{3}$ Art. 15 da Lei no $1.079 / 1950$.

${ }^{4} \$ 7^{\circ}$ do art. 218 do Regimento Interno da Câmara dos Deputados.

${ }^{5}$ Art. 20 da Lei no 1.079/1950 e $\$ 4^{\circ}$ do art. 218 do Regimento Interno da Câmara dos Deputados.

${ }^{6} \$ 5^{\circ}$ do artigo 218 do Regimento Interno da Câmara dos Deputados) e $\$ 1^{\circ}$ do artigo 20 da Lei no 1.079/1950.

${ }^{7}$ Art. 16 da Lei no 1.079/1950 e $\$ 11^{\circ}$ do artigo 218 do Regimento Interno da Câmara dos Deputados.

${ }^{8}$ Art. 22 da Lei no $1.079 / 1950$.

${ }^{9}$ Art. 18 da Lei no 1.079/1950).
} 
acusação não preencher os mínimos requisitos necessários para a configuração preambular do crime de responsabilidade, a denúncia deve ser rejeitada pela Comissão Especial. Porém, o juízo de admissibilidade feito pela Comissão deve ser aprofundado porque as consequências de uma imputação se desdobrarão nas fases seguintes e poderão afetar um agente político que foi sufragado pelo desejo democrático.

Na formação da Comissão Especial observar-se-á o princípio da proporcionalidade partidária, uma vez que é de fundamental relevância que as minorias partidárias sejam representadas. ${ }^{10}$ A Comissão Especial, concluído o parecer, lê-lo-á e publicá-lo-á no expediente na Câmara dos Deputados e no Diário Oficial da respectiva Casa Legislativa. ${ }^{11} \mathrm{O}$ parecer da Comissão será debatido pelos Deputados e submetido à votação nominal ${ }^{12}$.

\section{O PROCESSO DE IMPEACHMENT NO PLENÁRIO DA CÂMARA DOS DEPUTADOS}

Recebida a denúncia pela Comissão Especial, caberá ao Plenário da Câmara aprovar ou rejeitar a acusação. Rejeitada a acusação, o processo será arquivado. Se for aceita a denúncia, o processo seguirá para o Senado para que delibere sobre o mérito da acusação. O trâmite do processo de impeachment no Plenário da Câmara é apenas de ratificação ou indeferimento da denúncia. ${ }^{13}$ Nessa fase processual processada na Câmara é admitida a realização de diligências com objetivo de esclarecer determinados pontos da denúncia, todavia não é compatível com essa fase do processo a produção de provas que enfrentem o mérito da denúncia. O julgamento deve observar o teor da acusação previsto no relatório aprovado pela Comissão Especial.

Será admitida a abertura do processo de impedimento mediante a aprovação de dois terços de votos dos membros da Casa Legislativa mediante votação nominal. ${ }^{14}$ Acatada a denúncia, a Câmara dos Deputados enviará a comunicação formal ao Senado Federal para que delibere em juízo de admissibilidade e posteriormente sobre o mérito da acusação.

Porém, o que na verdade ocorre durante a votação de admissibilidade do processo de impeachment é que os Deputados Federais, salvo raríssimas exceções, votam de acordo com as suas convicções e seus interesses políticos sem qualquer preocupação jurídica, o que esvazia, significativamente, o real objetivo do processo de impedimento do mais alto agente político que foi sufragado pelo voto popular.

A hipótese de inobservância da finalidade pública que deveria nortear o processo de impeachment

\footnotetext{
${ }^{10}$ Art. 19 de Lei $1.079 / 1950$.

${ }^{11} \$ 2^{\circ}$ do art. 20 da Lei no $\left.1.079 / 1950\right)$ e $\$ 6^{\circ}$ do art. 218 do Regimento Interno da Câmara dos Deputados.

${ }^{12} \$ 8^{\circ}$ do art. 218 do Regimento Interno da Câmara dos Deputados.

${ }^{13}$ Art. 21 da Lei 1.079/1950.
} 
provoca, inegavelmente, o desvio de finalidade do Poder Legislativo com afronta aos dispositivos constitucionais e legais. Há inconstitucionalidade no desvio de finalidade porque a Constituição prevê que os parlamentares deliberem sobre o impedimento do Presidente de acordo com as normas constitucionais e não por meio de critérios subjetivos ou partidários. Há violação ao princípio da legalidade porque o rito do processo de impedimento está positivado na Lei no 1.079/1950 e não em convicções pessoais ou supostas ilações conjunturais políticas ou econômicas. Ora, muitos argumentos utilizados pelos Deputados Federais e por alguns Senadores para fundamentarem a admissibilidade do impeachment se consubstanciaram no cometimento de ilícitos pela Presidenta da República Dilma Rousseff no denominado "conjunto da obra”." Os Deputados Federais e Senadores entenderam por "conjunto da obra" os supostos desacertos políticos e administrativos cometidos pela Presidenta da República na condução do seu governo. Ou seja, os Deputados Federais e Senadores não se preocuparam se houve tipificação legal ou constitucional para que fosse configurado o crime de responsabilidade.

Os princípios da constitucionalidade e da legalidade (juridicidade) são a sustentação do Estado Democrático de Direito, sem os quais se eternizaria o dogma l'état c'est moi atribuído a um modelo de governo absolutista, o que inclui, sem dúvida, a usurpação do Poder Legislativo. Segundo o professor Luís Roberto Barroso, "nenhum ato contrário à Constituição pode ser válido. E a falta de validade traz como consequência a nulidade ou a anulabilidade. Ato inconstitucional é o ato nulo de pleno direito" (BARROSO, 2012, p. 37).

O princípio da legalidade sob o ponto de vista formal preserva a própria autoridade do Poder Legislativo e a hierarquia normativa em que a Constituição baliza os atos das autoridades públicas e protege o cidadão contra os atos de arbítrio (RIVERO; WALINE, 1996, p. 79). Pode-se dizer que qualquer decisão administrativa sem o respaldo dos princípios da constitucionalidade e da legalidade resulta "no funcionamento patológico do poder (demonia), associado à forte presunção da possibilidade de transgressão dos seus limites” (QUEIROZ, 2009, p. 285), ou no que conceitua Jorge Miranda, de "desvio de poder legislativo" (MIRANDA, 2013, p.40).

\section{O PROCESSO DE IMPEACHMENT NO SENADO FEDERAL}

Recebida a comunicação da Câmara com a autorização para a abertura do processo de impedimento, o Senado iniciará o processo mediante a observância de duas etapas processuais. A primeira etapa se dá com a distribuição da denúncia para uma Comissão Especial e a segunda etapa é feita pelo plenário. A Comissão Especial observará na sua composição, à semelhança do que ocorre na Câmara, a proporcionalidade partidária ${ }^{15}$. Competirá a Comissão Especial instruir o processo de acusação, coletar as provas necessárias, ouvir as partes

\footnotetext{
${ }^{14}$ \$9 do art. 218 do Regimento Interno da Câmara dos Deputados. Artigo com redação dada pela Resolução n 22, de 1992 e art. 23 da Lei no $1.079 / 1950$.
} 
interessadas e testemunhas. Contudo, a produção de provas nesta fase é apenas para deliberar sobre a admissibilidade da acusação.

Nessa fase processual não há juízo de mérito. Contudo, em respeito ao princípio do devido processo legal, é fundamental que a Comissão prestigie os meios necessários à ampla defesa, ainda que de forma sumária. Após o cumprimento de todas as formalidades instrutórias, a Comissão Especial deliberará, por maioria simples, se aceita ou recusa a denúncia. Recebida a denúncia, será encaminhada a peça de libelo para a apreciação pelo plenário do Senado, que também deliberará por maioria simples se aceita ou recusa a denúncia. Recusada a

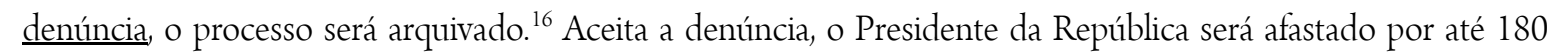
dias. ${ }^{17}$ Neste prazo será feito o juízo probatório elástico com a produção de todas as provas necessárias ao julgamento do mérito da acusação sob a presidência do Presidente do Supremo Tribunal Federal. ${ }^{18}$ Se o processo não for julgado no prazo de 180 dias, haverá o retorno do acusado. O Presidente do Supremo Tribunal Federal é a instância recursal natural para dirimir os conflitos que venham a ocorrer durante o julgamento do mérito do processo de impedimento.

No julgamento do Senado, segundo o parágrafo único do artigo 52 da Constituição Federal e do artigo 378 do Regimento Interno do Senado, há a obrigatoriedade de dois terços dos membros do Senado para que haja a condenação do acusado. No caso de autorização para abertura do processo, o Supremo Tribunal Federal entendeu que o quórum é de maioria simples, à semelhança do que ocorre para abertura do processo de julgamento de Ministros do STF e do Procurador Geral da República ${ }^{19}$.

A interpretação do Supremo Tribunal Federal que deu tratamento isonômico de quórum para abertura do processo de impedimento do Presidente, Vice-Presidente, Ministros do STF e o Procurador Geral da República é um duro revés para a democracia, uma vez que o Presidente da República é eleito pelo voto popular e mereceria um quórum qualificado. É muito mais viável a acusação conseguir a admissibilidade do processo por maioria simples do que com a maioria qualificada de dois terços. Neste caso, a interpretação do STF foi desfavorável ao réu e favorável ao acusador, até porque com a abertura do processo pelo plenário do Senado, o Presidente é afastado imediatamente da sua função por até 180 dias. Ora, se a Constituição é omissa quanto ao quórum para a abertura do processo de impedimento do Presidente da República, o STF deveria optar, hermeneuticamente, pelo princípio mais favorável ao acusado, ou seja, deveria a Suprema Corte adotar o quórum

\footnotetext{
${ }^{15}$ Art. 52 da Constituição Federal, artigo 24 Lei no 1.079/1950 e artigo 380 do Regimento Interno do Senado.

${ }^{16}$ ADPF 378-MC, rel. p/ o ac. min. Roberto Barroso, julgamento em 16-12-2015, Plenário, DJE de 8-3-2016.

${ }^{17}$ Constituição Federal, artigo 86, $\$ 11^{\circ}$, II e $\$ 2^{\circ}$.

${ }^{18}$ Constituição, art. 52, parágrafo único e parágrafo único do art. 377 do Regimento Interno do Senado Federal.

${ }^{19}$ Art. 24 da. Lei no 1.079/1950.
} 
que mais beneficiasse o réu. ${ }^{20}$

Os Ministros do STF e o Procurador Geral da República não podem ser igualizados ao Presidente da República por um motivo muito singelo: os Ministros do STF são indicados pelo Presidente da República e aprovados pelo Senado. O Procurador Geral da República, por sua vez, é escolhido pelos seus pares e pelo Chefe do Poder Executivo, enquanto que o Presidente da República é eleito pelo voto popular, a maior expressão da democracia representativa.

\section{Consequências do julgamento do mérito do processo de impeachment pelo Senado Federal}

O processo de impeachment, segundo previsto na Lei 1079/1950, estabelece que após o cumprimento de todas as formalidades inerentes à defesa do Presidente da República e ao respeito ao devido processo legal, o Senado proferirá a sentença. Se a sentença for absolutória, o réu será declarado inocente e retornará ao seu posto (art.32). No caso de condenação, segundo os artigos 33 e 34 da Lei 1079/1950, os efeitos são a destituição do cargo e inabilitação e para o exercício da função pública.

\section{As penas de perda do cargo público e inabilitação para o exercício de função pública}

No julgamento do impedimento da Presidenta Dilma Rousseff ocorrido no dia 21 de agosto de 2016, o Senado Federal, por iniciativa do Presidente do Supremo Tribunal Federal, condutor do processo de impedimento, resolveu dividir a votação a partir de um pedido de destaque apresentado pelo senador Randolfe Rodrigues (Rede-AP). No caso paradigmático, o Presidente do Supremo Tribunal Federal, por decisão monocrática em razão do destaque apresentado pelo partido político, colocou em votação em separado as duas penalidades: (1) perda do cargo e (2) inabilitação para o exercício de função pública.

No Mandado de Segurança 21689/DF²1 da relatoria do Ministro Carlos Velloso, o STF decidiu que "no sistema atual, da Lei 1.079, de 1950, não é possível a aplicação da pena de perda do cargo apenas, e nem a pena de inabilitação assume caráter de acessoriedade". Ou seja, à luz da intepretação dada pelo STF à época do impeachment do Presidente Fernando Collor de Mello, as penas de perda do cargo e inabilitação para o exercício de função pública são cumulativas. Há, a partir do caso concreto as seguintes possiblidades de interpretar a decisão do Senado Federal. (1) O suposto crime de responsabilidade não foi um crime grave (pedaladas fiscais e edição de decretos sem autorização do Congresso Nacional), sendo, assim, considerada gravosa demais a aplicação das

\footnotetext{
${ }^{20}$ Art. 38 da Lei 1070/1950.

${ }^{21}$ MS 21689/DF - Distrito Federal.
} 
duas penas, o que autoriza a aplicação do princípio da proporcionalidade para afastar a cumulação da pena com aplicação somente da perda do cargo. (2) A decisão do Senado Federal que dividiu as penas é matéria interna corporis e está imune de controle pelo Supremo Tribunal Federal, uma vez que a decisão se insere na categoria de matéria de mérito e não processual, o que afastaria o controle do STF, conforme já decidido na ADPF 378 MC/DF. (3) A decisão do Senado Federal que dividiu as penalidades viola o parágrafo único do artigo 52 da Constituição de 1988 porque as penas devem ser aplicadas cumulativamente, conforme já decido no precedente MS 21689/DF supracitado. Esta última hipótese me parece a mais razoável.

\section{A TIPIFICAÇÃO DOS CRIMES DE RESPONSABILIDADE NA CONSTITUIÇÃO DE 1988 E NA LEI $1.079 / 1950$}

As normas jurídicas são impositivas, cogentes e impõem deveres e responsabilidades. São imperativas e o seu descumprimento importará em sanção ao infrator. As normas jurídico-políticas estão previstas na Constituição e dependem de diversos fatores para que sejam aplicadas pelos atores políticos. A conjuntura histórica, social, econômica e política determinam a eficácia e a legitimidade dessa espécie normativa.

Paulo Brossard (1992, p. 75) deixou como legado doutrinário uma definição que se tornou clássica e é reproduzida à exaustão por muitos doutrinadores. Diz o saudoso jurista que tanto no direito brasileiro quanto no direito argentino, "o impeachment tem feição política, não se origina senão em causas políticas, objetiva resultados políticos, é instaurado sob considerações de ordem política e julgado segundo critérios políticos - julgamento que não exclui, antes supõe, é óbvio, a adoção de critérios jurídicos" (grifou-se). Destarte, ainda que o processo de impedimento reúna um conjunto de normas com feições políticas, as normas materiais e processuais estão sujeitas ao controle jurisdicional. A admissibilidade e o julgamento do impeachment são feitos por juízes políticos (Deputados e Senadores), mas o procedimento e o direito material são submetidos ao estreito controle do Poder Judiciário, conforme se pode observar do controle de legalidade e constitucionalidade feito pelo Presidente do Supremo Tribunal Federal, que éa instância última na condução do processo no âmbito do Senado Federal.

Evandro Lins e Silva (1992) faz uma análise severamente técnica e lúcida do papel do Senado Federal no julgamento do mérito do processo de impeachment: "no impeachment, a decisão do Senado não pode ser tachada de uma simples votação de lei ou de um mero ato do poder político. Tudo gira em torno uma regra constitucional, por um poder político da União, convertido em Tribunal”.

Na mesma linha de raciocínio, Manoel Gonçalves Ferreira Filho (1992) aduz que no "presidencialismo, o Presidente da República não é politicamente responsável perante o Congresso Nacional. Isto significa que, em última análise, não poder ele ser afastado do cargo por motivos e razões meramente políticas, como as que 
decorrem da desaprovação de sua política de governo, da orientação geral que imprime à ação governamental”. No presidencialismo, o Presidente desfruta de uma independência exclusiva na política nacional em razão de ter sido sufragado pelo voto popular MORRISON (2000, p. 42).

\section{A INTERPRETAÇÃO DOS CRIMES DE RESPONSABILIDADE}

A interpretação das hipóteses que configuram crimes de responsabilidade deve seguir a orientação da legalidade estrita da ciência penal. Segundo Juarez Tavares (2002, p. 30), o princípio da legalidade estrita "é aquele formalmente indicado pela lei como pressuposto necessário para a aplicação de uma pena, segundo a clássica fórmula nulla poena et nullum crimen sine lege". Assim, diante de uma interpretação estrita, "não pode qualificar como delito todos (ou somente) os fenômenos que considere imorais ou, em todo caso, merecedores de sanção, mas apenas (e todos) os que, independentemente de sua valoração, venham designados pela lei como pressupostos de uma pena”. Por último, aduz Juarez Tavares (2002, p. 31) que "o princípio da legalidade estrita é pressuposto como uma técnica legislativa específica, dirigida a excluir, conquanto arbitrárias e discriminatórias, as convenções penais referidas não a fatos, mas diretamente a pessoas e, portanto, com caráter constitutivo e não regulamentar daquilo que é punível”.

Na lição sempre atual do saudoso professor espanhol Eduardo García de Enterría (2001, p. 166-167), os princípios inspiradores da ordem penal são aplicáveis ao direito sancionador estatal, uma vez que um mesmo bem jurídico pode ser protegido por técnicas administrativas e penais. Assim, em caso de lacuna no quadro normativo administrativo, é possível a utilização de normas penais. A explicação para uma intepretação restritiva das normas que tipificam crimes de responsabilidade é pedagógica: os crimes de responsabilidade têm consequências gravíssimas porque podem demitir do mandato eletivo um Presidente da República eleito diretamente pelo sufrágio popular. Destarte, os dispositivos incriminadores que configuram crime de responsabilidade não permitem interpretação analógica, extensiva, teleológica ou de qualquer outro método hermenêutico que expanda o conteúdo do tipo específico. ${ }^{22}$ Dito de maneira imperativa, fora do catálogo discriminado pelos atos normativos que tipificam os crimes de responsabilidade deve ser afastada a denúncia. Ademais, a denúncia só tem validade enquanto o imputado exercer o mandato eletivo. Se, por qualquer motivo, o indigitado deixar definitivamente o cargo, a denúncia perderá o objeto. A insistência na aplicação da ciência penal subsidiariamente ao processo de impeachment decorre da observância do artigo 38 da Lei 1.079/50: "no processo e julgamento do Presidente da República e dos Ministros de Estado, serão subsidiários desta lei, naquilo em que lhes forem aplicáveis, assim os

${ }^{22}$ Sobre as interpretações declarativa, restritiva e extensiva, bem como sobre o método teleológico, cf. (PEIXINHO, 2015, p. 31 e 37) 
regimentos internos da Câmara dos Deputados e do Senado Federal, como o Código de Processo Penal”. Ora, por uma questão de lógica metódica e racionalidade jurídica, se o processo de impedimento segue o rito do processo penal numa aplicação subsidiária, as normas que configuram os crimes de responsabilidade se assemelham às normas penais materiais: são rígidas e inflexíveis e não autorizam que haja qualquer imputação se não houver previsão explícita nos catálogos punitivos das condutas reprováveis.

\section{AS DIFERENÇAS ENTRE OS ILÍCITOS ADMINISTRATIVOS E OS CRIMES DE RESPONSABILIDADE}

Os crimes de responsabilidade estão tipificados de forma exaustiva no artigo 85 da Constituição Federal e no artigo 4 da Lei 1079/1950, conforme visto anteriormente. Assim, quando se trata de processo sancionatório em que há restrição de direitos e de garantia, a interpretação do rol das tipificações deve ser restritiva, à semelhança do que ocorre com o direito penal e com o direito administrativo sancionador. O princípio da tipificação decorre diretamente do princípio da legalidade, a saber: "ninguém será obrigado a fazer ou deixar de fazer alguma coisa senão em virtude de lei" (art.5, II, CF/88). Por conseguinte, seria inconstitucional e ilegal a ampliação dos casos de crimes de responsabilidade fora dos estritos limites previstos nos atos normativos que regulam a matéria (OSÓRIO, 2000, p. 207-208).

A feição que se dá ao princípio da legalidade não se confunde com a observância doentia à literalidade das leis, mas, ao contrário, o princípio da legalidade significa, na lição sempre atual de Miguel Seabra Fagundes (2010, p. 116) "que todas as atividades administrativas são limitadas pela subordinação à ordem jurídica, ou seja, à legalidade... Onde há lei escrita, não pode haver arbítrio. Por outro lado, sendo a função administrativa, que constitui o objeto das atividades da Administração Pública, essencialmente realizadora do direito, não se pode compreender seja exercida sem que haja texto legal autorizando-a ou além dos limites deste”.

Assim, a função administrativa se caracteriza e deve definir-se por sua subordinação à lei (MALBERG, 2001, p.480). O recurso ao princípio da legalidade nos sentidos formal e substancial é indispensável à sustentação de legitimidade dos atos administrativos. Deve-se observar tanto a legalidade formal, ou seja, a vinculação dos atos administrativos ao estatuído pelo legislador, quanto à legalidade substancial, que impõe aos agentes públicos uma ação administrativa que penetra no próprio exercício do poder (CARINGELLA, 2010, p. 46).

No exame dos tipos definidos como crimes de responsabilidade, o ato administrativo que decidiu pela autorização de despesas sem que houvesse recursos suficientes para o pagamento dos gastos não é tipificado como crime de responsabilidade. No rol constante do artigo 85 da Constituição e no elenco do artigo $4^{\circ}$ da Lei 1079/1950 não está previsto o ilícito denominado "autorização de despesas não autorizadas e sem os recursos 
orçamentários". A acusação de que as "pedaladas" tiveram o objetivo de maquiar as contas públicas e majorar o déficit primário pode ser considerada uma decisão administrativa reprovável, mas não se constitui em crime de responsabilidade.

\section{A RESPONSABILIDADE PESSOAL DO PRESIDENTE DA REPÚBLICA NOS CRIMES DE RESPONSABILIDADE}

Um dos princípios fundamentais do direito administrativo é o princípio da hierarquia ou do poder hierárquico. A Administração Pública é composta de órgãos e de servidores públicos que são dispostos nas diversas instâncias administrativas a visar o cumprimento do interesse público. Segundo a lição sempre atual do saudoso professor Hely Lopes Meirelles (2008, p. 123), "o poder hierárquico é o de que dispõe o Executivo para distribuir e escalonar as funções de seus órgãos, ordenar e rever a atuação de seus agentes, estabelecendo a relação de subordinação entre servidores do seu quadro funcional”. Porém, o poder hierárquico deve ser compatibilizado com a desconcentração administrativa que visa a possibilitar que os diversos órgãos administrativos sejam ágeis, céleres e eficientes para que a máquina burocrática estatal ${ }^{23}$ alcance os objetivos perseguidos pelas políticas governamentais.

A desconcentração administrativa significa, de acordo com a lição do professor Celso Antônio Bandeira de Mello (2015, p. 154), "a distribuição interna de plexos de competências decisórias, agrupadas em unidades individualizadas". Segundo, ainda, o douto administrativista, a desconcentração "se faz em razão da matéria, isto é, em razão do assunto (por exemplo, Ministério da Justiça, da Saúde, da Educação), como em razão do grau (hierarquia), ou seja, do nível de responsabilidade decisória conferido aos distintos escalões que corresponderão aos diversos patamares de autoridades (por exemplo, diretor de Departamento, diretor de Divisão, chefe de Sessão, encarregado de Setor".

Ao discorrer sobre os princípios da organização do Poder Executivo, Alexandre Santos Aragão (2012, p. 106), cita, dentre os referidos princípios, o princípio da especialidade, que "é inerente à descentralização e à desconcentração administrativa, pela qual o estado destaca algumas de suas atividades para serem desempenhadas por determinadas entidades ou órgãos". O princípio da especialidade é fundamental na estrutura da organização administrativa porque não somente permite uma divisão de competência mais transparente, mas, também,

\footnotetext{
${ }^{23}$ A burocracia estatal, segundo Max Weber (1999, p.142-143) exige a presença de elementos estruturadores da organização estatal, dentre os quais podem ser enumeradas as competências legais e um quadro administrativo formado por servidores públicos com qualificação profissional estruturados em cargos públicos hierarquizados. A administração pública burocrática se exige a forma mais racional do exercício de dominação para que seja alcançada na finalidade estatal "o máximo de rendimento em virtude de precisão, continuidade, disciplina, rigor e confiabilidade
} 
possibilita melhor eficiência na prestação dos serviços públicos, uma vez que na figura do Presidente da República não podem ser concentradas todas as competências.

Os poderes do Presidente, segundo Queiroga Lavié (1987, p.230), são exercidos de forma individual, em razão de seus Ministros não formarem um colegiado, adotadas suas resoluções com unidade de decisão, a qual garante a eficácia e uniformidade na ação do Estado. No presidencialismo, os auxiliares do Presidente, a exemplo do Presidente, são responsáveis pelos atos de sua competência e há um vínculo de solidariedade com os outros agentes públicos que atuam nas diversas esferas de competência (ZARINI, 1999, p.802), porém a solidariedade não implica nem na ausência de autonomia das instâncias administrativas e nem na fragmentação das competências. Desta forma, os agentes públicos que auxiliam o Presidente da República atuam com autonomia e de acordo com regras de competência. Nestas regras, segundo Klaus Stern (1987, p. 286) são reconhecidas competências a determinados órgãos do Estado ou se delimitam esferas de competência entre órgãos do Estado. As competências dos órgãos públicos são esferas de atribuições que nem sempre são detalhadas, mas, ao contrário, são cláusulas abertas para possibilitar que a atuação Administração Pública seja dinâmica.

Dessa forma, é preciso concluir, preliminarmente, que há duas espécies de responsabilidades que não se confundem, quais sejam: a responsabilidade subjetiva do Presidente da República e a responsabilidade objetiva da administração pública. No Poder Executivo é preciso separar a responsabilidade do Presidente da República, que é o Chefe do Poder Executivo e de seus subordinados, Ministros, Secretários etc. Na aferição do crime de responsabilidade é preciso saber se a responsabilidade é subjetiva do Presidente da República ou se é dos agentes públicos que compõem o Poder Executivo.

Na peça de denúncia apresentada à Câmara dos Deputados, os denunciantes requereram ao Parlamento o recebimento da peça acusatória com fundamento nos dispositivos que supostamente configuram crime de reponsabilidade, quais sejam, o artigo 85, incisos V, I e VII, da Constituição Federal; nos artigos 4º, incisos V e VI; 9º, números 3 e 7; 10 números 6, 7, 8 e 9; e 11, número 3, da Lei 1.079/1950.

No exame detalhado dos diversos dispositivos citados, é de fácil percepção que os denunciantes não provaram que a Presidenta da República teve responsabilidade pessoal direta que violasse a probidade na administração, a lei orçamentária e o cumprimento das leis. A imputação genérica de responsabilidade não pode ser atribuída à Presidenta da República.

As normas constitucionais e legais que tipificaram os crimes de responsabilidade exigem que haja prova irrefutável de atuação dolosa do Presidente da República. As violações impostas pelos atos normativos punitivos somente são atos típicos se forem praticados pelo Chefe do Poder Executivo. Verifica-se, a título de comprovação histórica, que na denúncia feita contra o então Presidente Fernando Afonso Collor de Mello, os denunciantes, 
Barbosa Lima Sobrinho e Marcello Lavenere Machado (1993, p. 39) dizem, na peça de acusação, "que desde 15 de março de 1990, o denunciado, pessoalmente, bem como alguns de seus familiares - a mulher, a ex-mulher, a mãe - receberam indevidamente vultosas quantias em dinheiro, além de outros bens, sem indicação da origem lícita dessas vantagens". No libelo acusatório, o então Presidente foi acusado de ter mentido em razão da constatação de ter havido "depósitos feitos em sua conta por emitentes de cheques que usavam falsa identidade os fantasmas - projeções de P.C. Farias" (1993, p. 97). Como se pode observar do precedente histórico, a imputação por crime de responsabilidade ao Presidente da República deve ser pessoal e não cabe, assim, a acusação quando os ilícitos recaírem na responsabilidade de terceiros.

Quanto à acusação de que a Presidenta da República assinou decretos não autorizados pelo Parlamento, é preciso discorrer sobre a natureza dos referidos decretos. Segundo a peça de acusação, a Presidenta teria assinado 6 (seis) decretos de créditos suplementares no período que vai de 27 de julho até 20 de agosto de 2015 em suposta afronta à lei orçamentária. Haveria, com a assinatura dos decretos, a configuração do crime de responsabilidade.

O decreto é um ato administrativo composto que passa por diversas fases de elaboração e verificação de legalidade e legitimidade até que seja, na fase final, assinado pelo Presidente da República. São assim chamados atos administrativos compostos, segundo José dos Santos Carvalho Filho (2016, p. 136), porque ao contrário dos atos complexos, "não se compõem de vontades autônomas, embora múltiplas. Há, na verdade, uma só vontade autônoma, de conteúdo próprio. As demais são meramente instrumentais, porque se limitam a verificação de legitimidade do ato de conteúdo próprio". No decreto que autorizou a abertura de créditos suplementares intervieram diversas autoridades administrativas desde a concepção do ato até a assinatura do decreto pelo chefe do Poder Executivo.

Na organização administrativa é impossível que o Presidente da República detenha todo o controle das decisões técnicas pelos motivos a seguir discriminados. Em primeiro lugar, ao assinar o decreto que autorizou a abertura de créditos suplementares, o Presidente apenas homologou uma decisão já deliberada por diversas instâncias administrativas da área econômica. Em segundo lugar, a decisão executória que decidiu pela abertura de créditos suplementares não se constitui em crime de responsabilidade porque não está capitulado como delito imputável no rol dos deveres e obrigações presidenciais. Em terceiro lugar, a decisão de abertura de crédito suplementar prevista no inciso V do artigo 167 da Constituição, que prevê que "a abertura de crédito suplementar ou especial sem prévia autorização legislativa e sem indicação dos recursos correspondentes", não se configura ilícito porque os créditos estavam previstos no orçamento de 2015. 
Os supostos créditos suplementares de 2014 ficaram fora da denúncia acatada pelo Presidente da Câmara em razão da vedação constitucional prevista no artigo 86 , que obsta que Presidente possa responder por atos praticados anteriormente ao seu mandato. Não se pode, também, arguir, que o decreto presidencial violou o inciso VI do artigo 85 da Constituição Federal, que diz ser crime de responsabilidade os atos do Presidente da República que atentem contra a lei orçamentária. Atos atentatórios à lei orçamentária seriam se o Presidente da República não observasse todas as formalidades legislativas previstas no artigo 165 da Constituição Federal. Ademais, a Constituição Federal prevê que determinados investimentos são vinculados orçamentariamente. São desobediências ao orçamento público, por exemplo, a despesa com pessoal da União que ultrapasse $50 \%$ da receita líquida (art. 19, I da Lei Complementar no 101/2000). Assim, o disposto no parágrafo único do artigo $8^{\circ}$ é claro ao prescrever que "os recursos legalmente vinculados à finalidade específica serão utilizados, exclusivamente, para atender ao objeto de sua vinculação, ainda que em exercício diverso daquele em que ocorrer o ingresso". Desta forma, a inobservância estas regras específicas constituem desrespeito à lei orçamentária.

\section{O CONTROLE PELO SUPREMO TRIBUNAL FEDERAL DO MÉRITO DO PROCESSO DE IMPEACHMENT}

É corrente a afirmação - quase um senso comum - que o Supremo Tribunal Federal está obstado de examinar o mérito do processo de impedimento do Presidente da República por ser o referido julgamento um processo político. Destarte, estaria a Suprema Corte vinculada, exclusivamente, ao controle do processo e não do mérito do impeachment por ser o processo de impedimento do Presidente da República exclusivamente político. É verdade que o Senado Federal funciona no processo de impeachment, no dizer de José Afonso da Silva (2000, p. 132), como "um tribunal de juízo político". No plano dos crimes de responsabilidade, a Câmara dos Deputados à semelhança da pronúncia no processo penal - e o Senado Federal - que faz o juízo de mérito - na lição insuperável de Miguel Seabra Fagundes (2010, p. 168) - exercem uma função “tipicamente judicante”. Diz, ainda, o ilustre administrativista que por "seu caráter eminentemente político, não deixa o juízo de responsabilidade de se exercer por meio de um verdadeiro julgamento, com apuração do fato (delito), aplicação do direito (pena ou absolvição) e irretratabilidade (coisa julgada).

Na trilha da hermenêutica dominante da Constituição de 1988 e na intepretação do artigo 5o, XXXV, "a lei não excluirá da apreciação do Poder Judiciário lesão ou ameaça a direito". Este fundamento constitucional consagra a supremacia do Estado de Direito em que quaisquer atos administrativos, legislativos e jurisdicionais não podem ser imunizados se provocam lesão ao cidadão. Os atos ditos políticos, que afastam o controle jurisdicional, têm uma dimensão muito bem delineada: "são os que, embora administrativos na forma e na 
substância, ostentam finalidade exclusivamente política, circunscrita à atividade inter corporis da Administração Pública, e que, por esse motivo, não atinge, ao menos diretamente, direitos subjetivos dos administrados" (TUCCI, 1988, p. 93).

Na lição de Rui Barbosa (1933, 41-42), as questões políticas podem ser transformadas em questões jurídicas: "político fora da presença da justiça, um litígio pode assumir o caráter de judiciário, assumindo a forma regular de uma ação. $\mathrm{O}$ efeito da interferência da justiça, muitas vezes, não consiste senão em transformar, pelo aspecto com que se apresenta o acaso, uma questão política em questão jurídica”. E mais acentuadamente, fulmina Ruy Barbosa: "quando a pendência toca a direitos individuais, a justiça não se pode abster de julgar, ainda que a hipótese entenda com os interesses políticos de mais elevada monta”. Ora, como se pode ver dos doutos ensinamentos doutrinários, é inadmissível compreender, ainda que se considere ser o impeachment uma matéria política, que o Supremo Tribunal Federal não faça o controle de mérito dos crimes de responsabilidades previstos na Constituição e na Lei no 1.079/1950.

Os crimes de responsabilidades previstos no artigo 85 da Constituição de 1988 e na Lei no 1.079/1950 são numerus clausus e passíveis de controle de constitucionalidade e legalidade pelo Supremo Tribunal Federal porque podem afetar os direitos subjetivos do Presidente da República e dos demais agentes políticos que são submetidos ao julgamento do Senado Federal. Na função indeclinável de preservar a integridade da Constituição, o STF tem a última palavra, seja no controle do processo de impedimento quanto no controle de legalidade e constitucionalidade dos atos normativos que discriminam os crimes de responsabilidade. Nas palavras do Ministro Celso de Mello:

A interpretação constitucional derivada das decisões proferidas pelo Supremo Tribunal Federal a quem se atribuiu a função eminente de "guarda da Constituição" (CF, art. 102, "caput") assume papel de fundamental importância na organização institucional do Estado brasileiro, a justificar o reconhecimento de que o modelo político-jurídico vigente em nosso País conferiu, à Suprema Corte, a singular prerrogativa de dispor do monopólio da última palavra em tema de exegese das normas inscritas no texto da Lei Fundamental. ${ }^{24}$

Dessa forma, é inconcebível que um julgamento de impeachment regulado por normas legais e constitucionais que importam numa sanção gravíssima que pode demitir o mais alto agente político da República não possa ser objeto de controle de mérito pelo Poder Judiciário. Assim, não é razoável que seja firmado um precedente que interprete os crimes de responsabilidade como atos normativos interna corporis, conforme fica delineada neste julgado:

Impeachment. O direito a ser amparado pela via mandamental diz respeito à observância do regular processamento legal da denúncia. Questões referentes à sua conveniência ou ao seu

\footnotetext{
${ }^{24}$ MS 26603/ DF. Relator Min. Celso de Mello. Julgamento: 04/10/2007. Órgão Julgador: Tribunal Pleno Publicação 19-12-2008.
} 
mérito não competem ao Poder Judiciário, sob pena de substituir-se ao Legislativo na análise eminentemente política que envolvem essas controvérsias. ${ }^{25}$

O recebimento da renúncia e o julgamento do mérito feitos pelas Casas Legislativas no processo de impedimento devem estar em perfeita consonância com os princípios da constitucionalidade e da legalidade, fundamentos do Estado Democrático de Direito. A jurisdição constitucional do Supremo Tribunal Federal tem o dever histórico e indeclinável de apreciar as possíveis lesões decorrentes do julgamento dos crimes de responsabilidade pelo Senado Federal.

Ronald Dworkin tem uma lição doutrinária que me parece indispensável na hipótese de configuração de usurpações de autoridades públicas. Diz Dworkin que "os Estados Unidos são uma sociedade mais justa do que teriam sido se seus direitos constitucionais tivessem sido confiados à consciência de instituições majoritárias. Em todo caso, Marshall decidiu que os tribunais em geral, e a Suprema Corte em última instância, têm o poder de decidir pelo governo como um todo o que a Constituição pretende dizer, e de declarar inválidos os atos de outros órgãos públicos sempre que excedam os poderes que lhes são outorgados pela Constituição, corretamente entendida" (DWORKIN, 1999, pp. 426-427).

\section{CONCLUSÃO}

O processo de impeachment da Presidenta da República Dilma Rousseff teve grande repercussão nacional e internacional. Não foi um processo de impedimento em que houve consenso quanto à pratica de crime de responsabilidade. Os maiores juristas brasileiros se posicionaram contra o impeachment. Houve grande divisão na sociedade. Muitos brasileiros foram às ruas com manifestações favoráveis ao impedimento, mas também um quantitativo razoável de pessoais foi a favor da manutenção do mandato da Presidenta eleita. Todas as elites conservadoras sustentadas pela grande mídia fizeram campanhas ostensivas para desestabilizar o mandato presidencial. O Vice-Presidente, Michel Temer, um político decadente e representante dos blocos mais conservadores do país, articulou um golpe parlamentar com aliados na Câmara dos Deputados e no Senado Federal e assumiu o poder no lugar da Presidenta, o que não ocorreria numa situação de normalidade institucional.

A Presidenta da República somente foi afastada porque perdeu a maioria no Congresso Nacional, o que transformou o regime presidencialista num regime de coalização partidária com objetivos exclusivos de tomada do poder. Pode-se, assim, dizer que houve no Brasil num golpe parlamentar com aval do Supremo Tribunal Federal que se negou a examinar o mérito do processo de impeachment sob o argumento, no mínimo contestável, de que o processo de impedimento presidencial é norteado por decisões políticas da Câmara dos Deputados e do

\footnotetext{
25 (MS 30.672-AgR, rel. min. Ricardo Lewandowski, julgamento em 15-9-2011, Plenário, DJE de 18-10-2011.) Vide: MS 23.885, rel. min. Carlos Velloso, julgamento em 28-8-2002, Plenário, DJ de 20-9-2002.
} 
Senado Federal. Pura falácia. Há diversos precedentes em que o STF exerceu o controle de constitucionalidade de processos tipicamente políticos quando entendeu conveniente politicamente. Um dos exemplos mais recentes foi a suspensão do mandato parlamentar do Deputado Eduardo Cunha na Ação Cautelar 4.070 - DF por meio de uma decisão sem qualquer amparo constitucional. É verdade que o Deputado Eduardo Cunha praticava as mais variadas arbitrariedades no Parlamento, mas somente a Câmara dos Deputados poderia afastá-lo e não uma decisão judicial sem respaldo na Constituição. Porém, não foi o objetivo desse artigo analisar os aspectos sociais e políticos que subjazem o processo de impeachment.

No plano jurídico, sob a perspectiva do direito constitucional e do direito administrativo, que é o objetivo desse trabalho monográfico, após a análise dos principais dispositivos constitucionais, legais, doutrinários e da jurisprudência do Supremo Tribunal Federal-STF pertinentes ao processo de impedimento, podem ser sintetizadas as seguintes conclusões.

1. O rito processual adotado no caso de impedimento do Presidente da República está previsto na Constituição e regulamentado pela Lei no 1.079/1950 e pelos Regimentos Internos da Câmara dos Deputados e do Senado Federal, com as alterações feitas pelo STF na ADPF 378 MC/DF.

2. Há violação ao princípio da legalidade quando o rito legal do processo de impedimento positivado na Lei no 1.079/1950 se fundamenta em convicções pessoais ou supostas ilações conjunturais políticas ou econômicas.

3. A admissibilidade e o julgamento do processo de impeachment são feitos por juízes políticos (Deputados Federais e Senadores), mas o procedimento e o direito material são submetidos ao estreito controle do Poder Judiciário, conforme se pode observar do controle de legalidade e constitucionalidade feito pelo Presidente do Supremo Tribunal Federal no processo em trâmite no Senado.

4. O Presidente da República, no presidencialismo, não pode ser afastado do cargo por motivos e razões meramente políticas, como as que decorrem da desaprovação de sua política de governo, da orientação geral que imprime à ação governamental.

5. Na aplicação subsidiária do Código de Processo Penal ao processo de impedimento, a interpretação das hipóteses que configuram crimes de responsabilidade deve ser seguir a orientação da legalidade estrita da ciência penal.

6. As denominadas pedaladas fiscais e a utilização de decretos não autorizados que deram ensejo à abertura de créditos suplementares não são tipificados como crimes de responsabilidades pelo artigo 85 (I a VII) da Constituição Federal e nem pelo artigo 4o (I a VIII) da Lei 1079/1950.

7. De acordo com o princípio da hierarquia e da desconcentração administrativa, a responsabilidade por 
possíveis atos de irregularidades deve ser atribuída aos agentes públicos a que foram delegadas as competências administrativas, uma vez que as instâncias administrativas desconcentradas autorizam que os diversos agentes públicos atuem com autonomia administrativa no âmbito de suas competências.

8. Os atos tipificados como crimes de responsabilidade devem ser dolosos em razão da única e possível exegese prevista no artigo 85 da Constituição porque está evidente que os crimes de responsabilidade atribuídos ao Presidente da República são os atos que atentam contra a Constituição Federal.

9. Os crimes de responsabilidades previstos no artigo 85 da Constituição de 1988 e na Lei no 1.079/1950 são numerus clausus e passíveis de controle de constitucionalidade e legalidade pelo Supremo Tribunal Federal porque afetam os direitos subjetivos do Presidente da República e dos demais agentes políticos que são submetidos ao julgamento do Senado Federal.

10. É inconcebível que o STF no julgamento do processo de impeachment, regulado por normas legais e constitucionais, que pode importar numa sanção gravíssima, que é a demissão do mais alto agente político da República, não faça o controle de mérito. Não é razoável que seja firmado um precedente que interprete os crimes de responsabilidade como atos normativos interna corporis.

\title{
THE IMPEACHMENT PROCESS IN BRAZIL AND THE DEMOCRATIC STATE OF \\ LAW
}

\begin{abstract}
The impeachment process of the President of the Republic is a legal and political process regulated by the Constitution, regulated by Law No. 1,079 / 1950 and by the Internal Rules of the Chamber of Deputies and the Federal Senate. The Federal Supreme Court (STF) also regulated the impeachment process (ADPF 378 MC / DF) and gave new interpretation to the provisions of Law No. 1,079 / 1950 and the Internal Rules of the Chamber of Deputies and the Federal Senate. However, the STF understood that it was not within its competence to express itself on the merits of the impeachment process as being an exclusive competence of the Parliament, which meant a veiled consent to a parliamentary coup perpetrated by the conservative forces of the Brazilian elites and by the mainstream media. The deposition of the President of the Republic through the process of impeachment was a legal fraud and an opportunist parliamentary coup.
\end{abstract}

Keywords: Impeachment process; Legal and Political Process; Federal Constitution; Law No. 1,079 / 1950; Federal Court of Justice; Merit of the Impeachment Process; Legal Fraud; Parliamentary coup. 


\section{BIBLIOGRAFIA}

ARAGÃO, Alexandre Santos. Curso de Direito administrativo. Rio de Janeiro: Forense, 2012.

BABCOCK GOVE, Philip. WEBSTER'S. New International Dictionary of the English Language, 1961.

BANDEIRA DE MELLO, Celso. Curso de Direito Administrativo. São Paulo: Malheiros, 2015.

BARBOSA, Ruy. Comentários à Constituição Federal brasileira. São Paulo: saraiva, 1932.

BARROSO, Luís Roberto. O controle de constitucionalidade no Direito Brasileiro. 6a edição. São Paulo: Saraiva, 2012.

BLACK, M. A, Henry Campbell. Black's Law Dictionary. 6th ed., St. Paul, West, 1990. Law KF 156 B62 1990.

BROSSARD, Paulo. O Impeachment. São Paulo: Saraiva, 1992.

CALMON, Pedro. Curso de Direito Público. Rio de Janeiro: Freitas Bastos, 1938.

CARINGELLA, Francesco. Compendio de diritto admministratavio. Roma: Stampa, 2010.

CUNHA JUNIOR, Dirley. Curso de Direito Constitucional. 3a edição. Salvador: Editora Podvm, 2009.

DUVERGER, Maurice. Le système politique français. Paris: PUF, 1996.

DWORKIN, Ronald. O Império da lei. São Paulo: Martins Fontes, 1999.

ENTERRÍA, Eduardo García de e FERANANDEZ, Thomás-Ramon. Curso de Derecho Administrativo. Vol. II. Séptima edición. Madrid: Civitas, 2001.

FAGUNDES, M. Seabra. O controle dos atos administrativos pelo Poder Judiciário. Rio de Janeiro: Forense, 2010.

FERREIRA FILHO, Manoel Gonçalves. Comentários à Constituição Brasileira de 1988, vol. 2. São Paulo: Saraiva, 1992.

LAVIÉ, Queiroga. Curso de Direto Constitucional. Buenos Aires: Deplama, 1987.

QUEIROZ, Cristina. Direito Constitucional. São Paulo: RT; Ed. Coimbra, 2009.

MALBERG, R CARRÉ. Tradução de José Lión Depetre. Teoria general del Estado. México: Faculdad de Derecho, 2001.

MEIRELLES, Hely Lopes. Direito Administrativo. 34a edição. São Paulo: Malheiros, 2008.

MIRANDA, Pontes. Comentários à constituição de 1967. Tomo III. São Paulo: RT, 1967. 
MORRISON, Alan B. Funtamentals of American law. USA: Oxford University Press, 2000.

PEIXINHO, Manoel Messias. A Interpretação da Constituição e os princípios fundamentais. 4. ed. São Paulo: Atlas, 2015. Juris: 2010 .

As Teorias e Métodos de Interpretação aplicados aos Direitos Fundamentais. Rio de Janeiro: Lumen SILVA, José Afonso. Processo constitucional de formação das Leis. 2º edição. São Paulo: Malheiros, 2006.

STER, Klaus. Derecho del Estado de la Republica Federal da Alemana. Tradução de Javier pérez Royo y Pedro Cruz Villalón. Madrid: Centro de estudios Constitucionales, 1987.

RIVERO, Jean; WALINE, Jean. Droit administratif. 16e. 1996. Paris: Dalloz.

TAVARES, Juarez. Cognitivismo ou decisionismo. In FERAJOLI, Luigi. Direito e razão. São Paulo: RT, 2002.

TUCCI, Rogério Lauria. Constituição de 1988 e processo. São Paulo: Sariva, 1988.

ZARINI, Helio Juan. Derecho Constitucional. 2a edición. Buenos Aires: 1999.

WEBER, Max. Economia e sociologia. Vol. I 4a edição. Tradução de Regis Barbosa e Karen Elsabe Barbosa. Brasília: Brasília, DF: Editora Universidade de Brasília: São Paulo: Imprensa Oficial, 1999.

Trabalho enviado em 30 de abril de 2017.

Aceito em 28 de julho de 2017. 